\title{
Reviews on the Forming Process of Heat Treatable Aluminium Alloys
}

\section{Shamy Nazrein Md Yahaya ${ }^{1}$, Chuan Huat $\mathrm{Ng}^{1, *}$, Chee Fung Lai ${ }^{1}$, Faizal Sharrifuddin ${ }^{2}$, Karl Heinrich Grote ${ }^{3}$}

\author{
${ }^{1}$ Advance Forming Research Group (AFRG), Faculty of Mechanical and Manufacturing Engineering, Universiti Tun \\ Hussein Onn Malaysia, 86400 Batu Pahat, Johor, Malaysia \\ ${ }^{2}$ Hot Press Forming Department, MIYAZU (M) Sdn Bhd, Lot 1, Jalan Jelawai 1, Tanjung Malim, Perak \\ ${ }^{3}$ Lehrstuhl fuer Konstruktionstechnik, Institut fuer Machinenkonstruktion, Otto von Guericke University Magdeburg, \\ Universitaetsplatz 2, 39106 Magdeburg, Germany
}

Received 23 July 2018; accepted 27 August 2018, available online 30 October 2018

\begin{abstract}
Available forming process applied for heat treatable aluminium alloy were reviewed and presented in this paper. The reviews emphasized on the heat treatment, application and contribution of the forming methods. Forming methods discussed includes traditional, warm forming, hydroforming, superplastic forming, hot forming with in-die quench (HFQ) and hot press forming (HPF). The effects of forming processes towards heat treatable aluminium alloy were presented through the understanding on each process strengthening phenomena and the heat treating phenomena. These were to ensure better understanding on heat treatable aluminium alloy composition changes throughout forming process. Finally, concluding remarks the underline challenges of forming heattreatable aluminium alloy and subsequently highlights the potential work that can be applied in order to ensure a more efficient and sustainable manufacturing agenda for heat treatable aluminium alloy.
\end{abstract}

Keywords: Heat treatable aluminium alloy; heat treatment; forming process; sustainable manufacturing

\section{Introduction}

Heat treatment is the process of changing physical and mechanical properties of metal by heating and cooling it while retaining its shape. Apart from strengthening the materials, heat treatment method could also be used to improve other mechanical properties such as improving machinability, formability, and others. [1], mentioned that the most important process to strengthen aluminium alloys was the age hardening. The process of age hardening consists of three steps. First a solution heat treatment was performed to dissolve any relevant alloying elements in a solid. Second the material is quenched from solution treatment temperature with an appropriate cooling rate which keeps the solved alloying elements at solid solution. This state is called supersaturated solution. In a third step the material is aged, naturally (at room temperature) or artificially (temperatures usually up to $200^{\circ} \mathrm{C}$ ), for a certain time to get a controlled precipitation of strengthening particles.

In general, solution heat treatment involves heating the alloy to a suitable temperature, and holding it at that temperature for sufficient time to properly induce the constituents followed by rapid cooling to hold these constituents in solution. Quenching was a process involving rapid cooling to the metal formed at high temperature in order to gain certain properties of material. The method had been applied for hundreds of years but was perfected during the last century. Usually, the metals were quenched by submerging it into water, oil, air or brine to increase its hardness. There were lots of studies perform towards quenching process throughout the year showing the significance of this process. Through the use of quenching process, ultra-high strength steel parts with a tensile strength of $1.5 \mathrm{GPa}$ can be obtained [2].

During quenching, it was necessary to form a supersaturated solid solution in order to obtain effective precipitation of strengthening particles during aging. High quenching rate in a process proven to help achieve higher strengths material but if it was too high, increments in material residual stresses and distortion will occur [3]. Lastly, a stage known as precipitation hardening involve heat treating to the material imparting strength to metals and their alloys. It is called precipitation hardening as it makes use of solid impurities or precipitates for the strengthening process. Metals were aged through heating it or by keeping it stored at low temperatures to form precipitates to the materials [4]. Table 1 shows the parameters influencing results of heat treatment within input, function and output stages.

The quenching phase of a heat treatment process requires the use of appropriate cooling fluid, the quenchant to aid the rapid cooling process on the preheated alloy part. Surface temperatures of the material during the start of quenching are typically very large, corresponding to the film boiling regime. Typically, 
during quenching the heat removal from the surface involved combination of conduction across the vapor blanket and radiation heat transfer. Eventually, the temperature will decreases asymptotically to the quenchant temperature and diminishes a single-phase regime toward the surface resulting high strength properties sought within the material [5].

Table 1: Parameters influencing the result of heat treatment [4]

\begin{tabular}{|c|c|c|c|}
\hline \multicolumn{4}{|c|}{ Parameters influencing results in heat treatment } \\
\hline Stages & Input & Function & Output \\
\hline Conditions & $\begin{array}{c}\text { Workpiece } \\
\text { (Before heat } \\
\text { treatment) }\end{array}$ & $\begin{array}{c}\text { Heat } \\
\text { Treatment } \\
\text { Process } \\
\end{array}$ & $\begin{array}{c}\text { Heat- } \\
\text { treated } \\
\text { workpiece }\end{array}$ \\
\hline $\begin{array}{c}\text { Parameters } \\
\text { / Factors }\end{array}$ & $\begin{array}{c}\text { Geometry } \\
\text { Chemical } \\
\text { Composition } \\
\text { Material } \\
\text { Condition }\end{array}$ & $\begin{array}{l}\text { Temperature } \\
\text { Time } \\
\text { Medium } \\
\text { during } \\
\text { heating, } \\
\text { soaking and } \\
\text { cooling }\end{array}$ & $\begin{array}{c}\text { Desired } \\
\text { change in } \\
\text { workpiece } \\
\text { properties } \\
\text { Side effect } \\
\text { changes of } \\
\text { (1) Macro } \\
\text { geometry; } \\
\text { (2) Micro } \\
\text { geometry; } \\
\text { (3) } \\
\text { Surface } \\
\text { layer } \\
\text { condition } \\
\text { (4) } \\
\text { Residual } \\
\text { Stress }\end{array}$ \\
\hline
\end{tabular}

\section{Forming process on Aluminium Alloys}

Due to the low formability of aluminium alloys (Alalloy), particularly at room temperature, the forming technology was restricted. Therefore, advanced forming methods are essential in improving their formability. Alalloy sheet components in either T4 or T6 conditions are normally cold formed. This causes a number of intrinsic problems, such as springback and low formability. The frequent solution for low formability problems is to form the material at high temperatures. When the temperature was raised, the ductility of the material will increase and yield strength decrease. This results in less forces being required for the deformation. Hot stamping can eliminate springback and increase formability, but the desired microstructure were destroyed [6]. Hence, solution heat treatment (SHT) is required to restore the microstructure, but distortions of the formed components will occur during quenching. Various efforts have been undertaken and special processes have been invented to overcome specific problems in forming particular types of components [3].

\subsection{Traditional Cold Forming}

Cold-rolled steel sheet is the traditional manufacturing process for automotive body panels. There were many attempts by automotive manufacturers to reduce their vehicle weight by using $\mathrm{AA} 5 \mathrm{xxx}$ and AA6xxx aluminum alloys as their vehicle components part. AA6xxx which was age hardened material are normally formed either in its T4 condition (solution heat treated and quenched), followed by artificial ageing for higher strength, or in its T6 condition (solution heat treated, quenched and artificially aged) [7],[8]. The material is first heated to its Solution Heat Treatment (SHT) temperature and held for a sufficient period of time. Within this period, all precipitates are taken into the matrix giving one single phase. The heat-treated material was then rapidly cooled to room temperature to freeze this super-saturated state within the material. Once the material has been thermally treated and modified to the required mechanical properties, it is cold-deformed in the T6 condition into the required shape [9].

There are significant drawbacks of this traditional method in forming aluminum alloys panel parts. With the hardening and strengthening of the material, the material will faced with poor formability problems. Apart from that, for material with low young's modulus, the component will be more likely to be affected by springback and wrinklings problems. All these is drawbacks that will results more effort just to compensate it.

\subsection{Preforming, Annealing, and Finish Forming}

This forming process involves drawing the blank as deep as possible without necking. The process then followed by annealing the blank at about $350^{\circ} \mathrm{C}$ so that the cold working stresses can be removed [10]. The process then followed by drawing it to its final shape. This process has a high cycle time especially within the process transfers. This process was seen to be very disadvantageous due to low hardness value measured for the formed parts. Hardness measurement shows that this process was not able to fully anneal the materials, which leads to not achieving the original hardness of the incoming material. Apart from that, this is not a one-step process and the cost associated with extra processing steps makes this process cost-prohibitive.

\subsection{Warm Forming}

The limited ductility for aluminum at cold forming condition was improved significantly through Warm forming process. However, many challenges are faced in such process which includes (1) heating the components; (2) controlling process temperature; (3) lubrication during the process; (4) selection of the appropriate forming press; (5) cycle time; and (6) increment in production cost. The die system in this process requires complex heating strategies, resulting high tooling cost and relatively slow cycle time. Achieving uniform temperature condition and maintain a steady die temperature are very hard to be done during the process. In this process, the aluminum alloy blank will be heated between $\left(240-260^{\circ} \mathrm{C}\right)$ and then formed in a conventional hydraulic press at room temperature [10]. 
Recent study conducted for Automotive Research (USCAR) shows that for situations requiring only heated sheet metal and room temperature dies, non-isothermal elevated temperature forming technology was used. The purpose of the study was to optimize the technology in terms of part cost and production data. Another study shows that, at room temperature, the $5 \mathrm{xxx}$ series aluminum alloys can be formed which have the largest formability range, but also the lowest yield and tensile strength [11]. The $7 \mathrm{xxx}$ series alloys have the highest strength and then the $6 \mathrm{xxx}$ series. The $7 \mathrm{xxx}$ series with T6 temper cannot be formed at room temperature. The formability of this alloy can be improved with elevatedtemperature forming. Either warm forming (less than $250^{\circ} \mathrm{C}$ degrees) or hot forming (about $475^{\circ} \mathrm{C}$, the alloy's solvus temperature) can be used. Forming of aluminum alloy sheet at high temperature produce a product has a different microstructure and mechanical properties than the original sheet or it may remove any heat treatment has been done to the sheet. The side impact beams in the BMW cars are formed from $7 \mathrm{xxx}$ aluminum alloy fully hardened $\mathrm{T} 6$ temper in the $200^{\circ} \mathrm{C}$ temperature range with forming speed equal to that used in traditional cold forming of aluminum alloys.

\subsection{Hydroforming Process}

In the hydroforming process, pressure was applied to the sheet metal to form it into a desired component shape. Hydroforming is a manufacturing process specifically for high formability materials and may be used as an alternative process to cold deep drawing [12]. In contrast to tube hydroforming in which the pressure can be easily sealed, sheet hydroforming requires a rubber membrane to ensure the high pressure fluid does not escape. This process complex steps and complicated tooling affects its reliability. The process has made a little impact in the mass-production of sheet aluminium components. Hydroforming process were mainly applied for automotive industries, specifically in manufacturing exhaust parts, radiator frames, front and rear axles, engine cradles, body parts and space frames [9]. The hydroforming process main advantages are the process may reduce the number of required joints and increase material utilization.

\subsection{Superplastic Forming (SPF) of Sheet Metal Components}

Superplastic forming is a slow forming process designed to achieve a significant increase in formability. The superplastic forming has been applied a lot for aerospace applications due to its ability to form complex shaped lightweight components [13]. Fine grains equiaxed with average grain sizes typically around $5 \mu \mathrm{m}$ are required in order to achieve its superplastic deformation. In addition, the temperatures in excess of half the melting point are required to enable the diffusion processes to occur. However, under these conditions, grain growth will takes place by static diffusion controlled processes, which leads to enhancement in material deformation [13]. The grain growth causes the material to harden and decreases the strain-rate sensitivity and in turn decreases the elongation to failure.

Uncontrolled grain growth was prevented in twophase systems, such as in forming the titanium alloy (Ti6Al4V) due to the presence of the low diffusivity alpha phase, which constrain the growth of the higher diffusivity beta phase [14]. Superplastic forming was usually achieved using particular processes such as thermoforming, blow forming, and vacuum forming. Post-forming heat treatment (e.g. SHT + Quenching + Ageing for Heat-treatable Al-alloys) is required to obtain appropriate microstructure in formed materials [13],[15],[16]. The major advantage of the superplastic forming process was the excellent surface finish and the shape precision for the finished products [17]. Moreover, the finished product does not suffer any springback or residual stresses. Apart from that this process allows the manufacturing of large complex shapes parts which can be deformed in one operation.

The main disadvantage of the superplastic forming process is its slow forming rate. The forming process time varies from two minutes to a few hours. Hence, this process is unsuitable for mass production [13]. Recently, superplasticity has been used to form components for automotive applications. In the automotive industry, aluminium alloys are deformed at a faster rate (in contrast to aerospace applications) to provide high volume production. The significant increase in the formability of aluminium alloys by using superplastic forming allows for more complex shape and eliminate the use of fasteners and joints in parts [10]

\subsection{Hot Forming and in-Die Quenching (HFQ) Processes}

Based on an analysis of the average compound annual growth rate (CAGR), there were high potential for the increment in the use of aluminium part within car body [18]. Aluminium part is seen to contribute most on the weight of the vehicle as it gave a share of between $25 \%$ and $30 \%$ of the complete car's mass, depending mainly on options installed, integrated safety features, and engine size.

However, there were major problems such as springback, poor formability and microstructure in producing aluminum alloy panel components. Henceforth, a novel process known as Hot Forming and in-die Quenching process (HFQ) was proposed by [19] in recent years. There are three main steps in this process which started with Solution Heat Treatment (SHT). In SHT, the alloying elements are fully dissolved into solid aluminium due to the sheet blank being soaked at an elevated temperature for a sufficient period of time. The process continues with hot forming and die quenching where the hot blank is transferred to a cold die set where it is quickly formed and held within the dies until quenched to room temperature, which leaves the alloying elements in the unstable solid solution. Lastly, the process 
will undergo artificial aging. In artificial aging or agehardening, the properties of the heat treatable aluminium alloys are improved. This was due to in appropriate aging time and temperature, the alloying elements comes out of the solid solution and form strengthening particles. Temperature changes over time for HFQ process is shown in Figure 1.

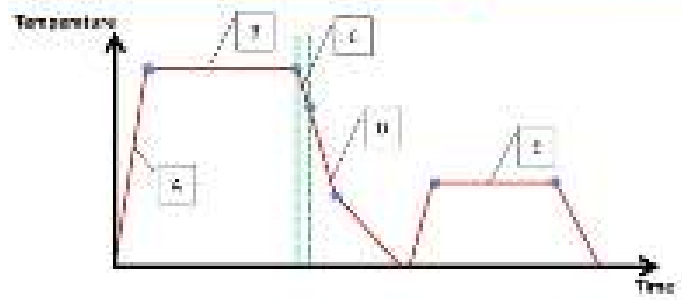

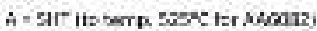

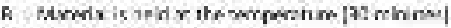

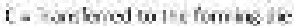

C-inutla

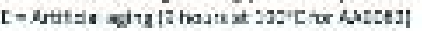

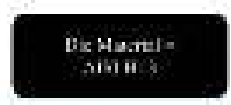

Figure 1: Temperature over process time in HFQ process [19]

However, the use of HFQ process in forming the aluminium alloys take a long time due to the need of blank being dissolved over a period of time in the solution heat treatment process [20].

\subsection{Hot Press Forming (HPF) Process}

HPF is a forming and tempering process when the metal sheet is heated up to relative high temperature, where austenite microstructure is formed. Followed by forming operation, and then the metal sheet is cooled down rapidly by using water, oil or air as medium, resulting in martensitic microstructure. Through the combination of heating, holding, forming and rapid cooling, complex parts can be produced with excellent strength properties. Figure 2 shows the temperature change with time in hot press forming.

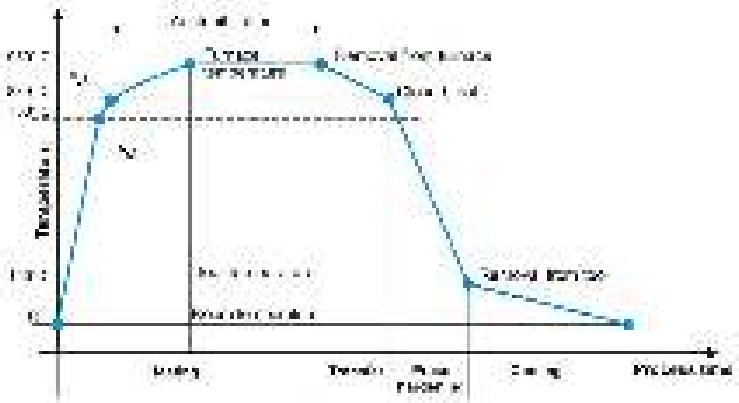

Figure 2: Temperature over process time for hot press forming (HPF) [21]

Hot press forming can be classified into 2 kinds of processes, which are direct hot press forming (DHPF) and indirect hot press forming (IHPF). For DHPF, the metal sheet is directly austenitized, then undergo forming process and cooled down rapidly. Eventually the part has excellent strength properties [21]. For IHPF, before transferred to heating furnace, the metal sheet is cold deforming to about $90 \% \sim 95 \%$ of its final shape, also known as pre-forming stage [22]. IHPF method is suitable for producing the large dimensions and complex part. Figure 3 shows two different hot press forming process which are direct and indirect hot press forming.

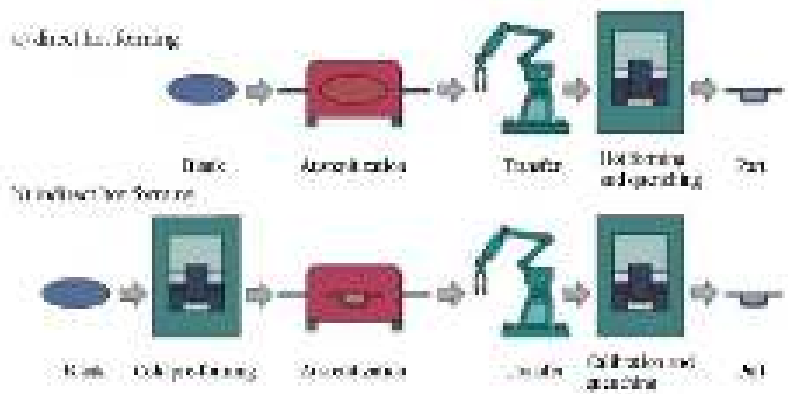

Figure 3: Direct (a) and indirect (b) process chain in hot press forming [23]

Basically, hot forming process includes five basic steps which includes: 1) Blanking; 2) Heating of the blank to its martensite condition; 3) Transferring from furnace to press machine; 4) Press forming; and 5) Quenching by the die through heat conduction. The time taken for steps in the hot forming process plays a major role in determining the total production time and the cycle time for every production [22]. The time taken within the transferring can also help in determining the heat loss to the environment. The heat loss can then be taken into account of determining the forming temperature. Table 2 shows the time required for a process in the hot forming process obtained from several resources.

Table 2: The time required for a process in the hot forming process with resources

\begin{tabular}{|c|c|c|}
\hline Process & $\begin{array}{l}\text { Time } \\
\text { Taken }\end{array}$ & Resources \\
\hline $\begin{array}{l}\text { Austenized at } \\
950^{\circ} \mathrm{C}\end{array}$ & $\begin{array}{c}18 \mathrm{sec} \\
\text { (induction) } \\
300 \mathrm{sec} \\
\text { (furnace) } \\
300 \mathrm{sec} \\
\text { (furnace) } \\
260 \mathrm{sec} \\
\text { (furnace) } \\
300 \mathrm{sec} \\
\text { (furnace) } \\
240 \mathrm{sec} \\
\text { (furnace) }\end{array}$ & $\begin{array}{c}\text { Katsuyoshi Ikeuchi } \\
\text { et al.(2011) [24] } \\
\text { Wei et al. (2012) } \\
\text { [25] } \\
\text { Nuraini Aziz et al. } \\
\text { (2013) [26] } \\
\text { Bardelcik et al. } \\
\text { (2010) [27] } \\
\text { Etienne J.F.R. et al. } \\
\text { (2014) [28] } \\
\text { Chang Ying et al. } \\
\text { (2011) [29] }\end{array}$ \\
\hline $\begin{array}{l}\text { Transfer from } \\
\text { furnace to hot } \\
\text { press }\end{array}$ & $\begin{array}{l}7-15 \mathrm{sec} \\
7.5 \mathrm{sec}\end{array}$ & $\begin{array}{l}\text { Nuraini Aziz et al. } \\
\quad(2013)[26] \\
\text { Katsuyoshi Ikeuchi } \\
\text { et al.(2011) [24] }\end{array}$ \\
\hline $\begin{array}{l}\text { Press forming } \\
\text { and quenching }\end{array}$ & $\begin{array}{l}1-10 \mathrm{sec} \\
5-11 \mathrm{sec}\end{array}$ & $\begin{array}{l}\text { Katsuyoshi Ikeuchi } \\
\text { et al.(2011) [24] } \\
\text { Nuraini Aziz et al. } \\
\text { (2013) [26] }\end{array}$ \\
\hline
\end{tabular}


Hot stamped part produced are made from boron steel which includes chassis components, such as Apillar, B-pillar, bumper, roof rail, rocker rail and tunnel. The die used in the hot forming process has a cooling system which helps drastically in promoting final product with good properties and high tensile strength [29]. In order to achieve an effective rapid cooling during the hot stamping process, the die should promote greater thermal conductivity value. Hence, the suitable material to produce the dies is high thermal conductivity steel (HTCS-150). This steel was patented in 2013 and the machining process for this material must be highly accurate in order to achieve high quality of stamped components [24]. This hot work tool steel possessed very high thermal conductivity values (up to $66 \mathrm{~W} / \mathrm{mK}$ ) and a high wear resistance. It is specially designed to be used as dies of hot stamping on coated sheet and plastic injection mould, where the plastic material is reinforced with abrasive fiber materials and closed die forging. HTCS150 obtains its optimized mechanical and physical properties through a corresponding heat treatment of the material prior to final machining.

\section{Developments in Aluminium Alloys}

New developments in aluminum alloys have opened a wide range of applications of wrought aluminum in place of aluminum castings. Wrought aluminum alloys are produced from cast ingots, which are prepared for subsequent mechanical processing [30]. The microstructures and mechanical properties of wrought aluminum alloys are significantly dependent on various working operations and thermal treatments. The improvement of aluminium alloy mechanical properties by adding various alloying elements has opened a wider field of applications for these alloys, particularly in the aerospace and automotive industries [31].

Highest demand of application was seen for aluminium alloys in the $7 \mathrm{xxx}$ series. Zinc is the primary alloying agent for this series, and the small addition of magnesium to the series makes it heat treatable and very high strength alloy. Other elements such as chromium and copper may also be added in small quantities. The most commonly used alloys in this series are 7050 and 7075, which are widely used in the aircraft industry. Apple's aluminum Watch that released in year 2015 was made from a custom $7 \mathrm{xxx}$ series alloy. In compare to $6 \mathrm{xxx}$ series alloy, the strength to weight ratio of $7 \mathrm{xxx}$ is optimum for security crash components and the most efficient in cost per $\mathrm{kg}$ saved. The main disadvantage of $7 \mathrm{xxx}$ series is its reduced formability in room temperature. Henceforth, the metal had to be formed at elevated temperature in order to improve formability.

However, the final properties of this material degrade when it is formed at elevated temperature. A recent study shows that pertinent pre-treatment condition and deformation temperature can ensure sufficient formability for 7xxx series alloy. Apart from that, AA7075 tubes was warm hydroformed at a temperature of $300{ }^{\circ} \mathrm{C}$ and significant improvement of formability was achieved [32]. Wang et al. [33] presented a paper where material characterization of AA7075-T6 material was performed. It was discovered that the total elongation at fracture increased at temperature between $140{ }^{\circ} \mathrm{C}$ and $220^{\circ} \mathrm{C}$. This was due to the increase in strain rate sensitivity, which prevents plastic strain from concentrating in a localized neck and reduce diffuse necking.

\section{Conclusions}

In this paper, several available types of forming methods for aluminium alloys were presented and explained. Each forming method were explained and summarized with its process sequence and advantages. The two main industries that benefit most from aluminium alloys were the automotive and aerospace industries. The use of aluminium alloys ensure brighter future since its usage is almost limitless and ensure a more sustainable and greener environment.

\section{Acknowledgement}

The authors would like to express their gratitude to Universiti Tun Hussein Onn Malaysia (UTHM) and Miyazu (M) Sdn Bhd for supporting these research activities. The authors would also like to express special thanks to UTHM Research Management Center (RMC UTHM) - Tier 1 Grant and Centre of Graduate Studies UTHM for funding this research work.

\section{References}

[1] Milkereit, B. , Kessler, O. , and Schick, C. Recording of continuous cooling precipitation diagrams of aluminium alloys, Thermochimica Acta, Volume 492 (2009) pp. 73-78.

[2] Takahashi, A., Mori, E. , and Ohnishi, T. The foci of DNA double strand break-recognition proteins localize with $\gamma \mathrm{H} 2 \mathrm{AX}$ after heat treatment, Journal of radiation research, Volume 51 (2010) pp. 91-95.

[3] Reich, M. and Kessler, O. Mechanical properties of undercooled aluminium alloys and their implementation in quenching simulation, Materials Science and Technology, Volume 28 (2012) pp. 769-772.

[4] Gao, H., Politis, D. J., Luan, X., Ji, K., Zhang, Q., Zheng, Y., Gharbi, M., and Wang, L. In Forming limit prediction for AA7075 alloys under hot stamping conditions, In Journal of Physics: Conference Series, Volume 896 (2017) p. 012089.

[5] Edmonds, D. V , He, K. , Rizzo, F. C. , Cooman, B. C. De , Matlock, D. K. , and Speer, J. G. Quenching and partitioning martensite-A novel steel heat treatment, Materials Science and Engineering: A, Volume 438 (2006) pp. 25-34.

[6] Foster, A. D. , Mohamed, M. S. , Lin, J. , and Dean, T. A. An investigation of lubrication and heat transfer for a sheet aluminium heat, form-quench (HFQ) process, Steel Research International, (2008) pp. 113-120.

[7] Carle, D. and Blount, G. The suitability of aluminium as an alternative material for car bodies, 
Materials \& design, Volume 20 (1999) pp. 267-272.

[8] Ab Kadir, M. I. , Mustapa, M. S. , Rosli, N. L. , Yahya, M. S. , Mohamad, M. A. H., and Rahim, A. K. A. The Effect of Microstructures and Hardness Characteristics of Recycling Aluminium Chip AA6061/Al Powder On Various Sintering Temperatures, International Journal of Integrated Engineering, Volume 10 (2018)

[9] Mohamed, M. S. and Ismail, A. In Review on sheet metal forming process of aluminium alloys, 17th International Conference on Applied Mechanics and Mechanical Engineering, (2016) pp. 129-141.

[10] Jeswiet, J. , Geiger, M. , Engel, U. , Kleiner, M. , Schikorra, M. , Duflou, J. , Neugebauer, R. , Bariani, P. , and Bruschi, S. Metal forming progress since 2000, CIRP Journal of Manufacturing Science and Technology, Volume 1 (2008) pp. 2-17.

[11] Fakir, O. El , Wang, L. , Balint, D. , Dear, J. P. , Lin, J. , and Dean, T. A. Numerical study of the solution heat treatment, forming, and in-die quenching (HFQ) process on AA5754, International Journal of Machine Tools and Manufacture, Volume 87 (2014) pp. $39-48$.

[12] Cai, J., Lin, J., and Dean, T. A. In A novel process: Hot stamping and old die quenching, Journal of Machine Tools and Manufacture, Volume 53 (2007) pp. 27-38.

[13] Serra, D. Superplastic forming applications on aero engines. a review of ITP manufacturing processes, EuroSPF08 (2008).

[14]Kim, T.-W. and Dunne, F. P. E. In Modelling heterogeneous microstructures in superplasticity, The Royal Society (1999).

[15] Lin, J. , Dean, T. A. , and Garrett, R. P. A process in forming high strength and complex-shaped Al-alloy sheet components, UK Patent, (2008)

[16] Abu-Farha, F. K. and Khraisheh, M. K. An integrated approach to the superplastic forming of lightweight alloys: towards sustainable manufacturing, International Journal of Sustainable Manufacturing, Volume 1 (2008) pp. 18-40.

[17] Ganesh, P. Finite element simulation in superplastic forming of friction stir welded aluminium alloy 6061-T6, International Journal of Integrated Engineering, Volume 3 (2011)

[18] Fan, X. , He, Z. , Yuan, S. , and Lin, P. Investigation on strengthening of 6A02 aluminum alloy sheet in hot forming-quenching integrated process with warm forming-dies, Materials Science and Engineering A, Volume 587 (2013) pp. 221-227.

[19] Lin, J., Schwarz, G., and Heinritz, M. Process for forming aluminium alloy sheet component. US Patent, (2012).

[20] Garrett, R. P. , Lin, J. , and Dean, T. A. An investigation of the effects of solution heat treatment on mechanical properties for AA $6 \mathrm{xxx}$ alloys: Experimentation and modelling, International Journal of Plasticity, Volume 21 (2005) pp. 16401657.
[21] Mikl, T. Hot Press Forming In Sheet Metal Forming, Volume 2 (2014) pp. 1-9.

[22] Lee, M. G. , Kim, S. J. , Han, H. N. , and Jeong, W. C. Application of hot press forming process to manufacture an automotive part and its finite element analysis considering phase transformation plasticity, International Journal of Mechanical Sciences, Volume 51 (2009) pp. 888-898.

[23] Karbasian, H. and Tekkaya, a. E. A review on hot stamping, Journal of Materials Processing Technology, Volume 210 (2010) pp. 2103-2118.

[24] Ikeuchi, K. and Yanagimoto, J. Valuation method for effects of hot stamping process parameters on product properties using hot forming simulator, Journal of Materials Processing Technology, Volume 211 (2011) pp. 1441-1447.

[25] Wei, L. , Liu, H. , Xing, Z. , Gang, L. , and Jun, B. Effect of tool temperature and punch speed on hot stamping of ultra high strength steel, Transactions of Nonferrous Metals Society of China, Volume 22 (2012) pp. 534-541.

[26] Aziz, N. and Aqida, S. N. Optimization of quenching process in hot press forming of $22 \mathrm{MnB} 5$ steel for high strength properties for publication in, IOP Conference Series: Materials Science and Engineering, Volume 50 (2013) pp. 012064.

[27] Bardelcik, A. , Salisbury, C. P. , Winkler, S. , Wells, M. a. , and Worswick, M. J. Effect of cooling rate on the high strain rate properties of boron steel, International Journal of Impact Engineering, Volume 37 (2010) pp. 694-702.

[28] Caron, E. J. F. R. , Daun, K. J., and Wells, M. A. Experimental heat transfer coefficient measurements during hot forming die quenching of boron steel at high temperatures, International Journal of Heat and Mass Transfer, Volume 71 (2014) pp. 396-404.

[29] Chang, Y. , Meng, Z. H. , Ying, L. , Li, X. D. , Ma, $\mathrm{N}$. , and $\mathrm{Hu}, \mathrm{P}$. Influence of hot press forming techniques on properties of vehicle high strength steels, Journal of Iron and Steel Research International, Volume 18 (2011) pp. 59-63.

[30] Polmear, I. J. Light alloys, metallurgy of the light alloys, Metallurgy and Materials Science, Arnold, Great Britain, (1995) pp. 168-195.

[31] Kleiner, M. , Chatti, S. , and Klaus, A. Metal forming techniques for lightweight construction, Journal of Materials Processing Technology, Volume 177 (2006) pp. 2-7.

[32] Lee, M.-Y., Sohn, S.-M. , Kang, C.-Y., Suh, D.-W. , and Lee, S.-Y. Effects of pre-treatment conditions on warm hydroformability of 7075 aluminum tubes, Journal of Materials processing technology, Volume 155 (2004) pp. 1337-1343.

[33] Hui, W. , LUO, Y. , Friedman, P. , CHEN, M. , and Lin, G. A. O. Warm forming behavior of high strength aluminum alloy AA7075, Transactions of Nonferrous Metals Society of China, Volume 22 (2012) pp. 1-7. 